\title{
AUTOMATIC AND MANUAL SPRAY BAR SECTIONS CONTROL
}

\section{PEDRO H. WEIRICH NETO ${ }^{1}$, RODERIK W. V. D. MEER ${ }^{2}$, PETER VINK ${ }^{3}$, ALTAIR JUSTINO $^{4}$, LUIZ C. GARCIA ${ }^{5}$}

\begin{abstract}
The use of precision farming tools in pesticide application technology can improve the techniques effectiveness during the spraying. Thus, this study aimed to compare automatic and manual systems to interrupt the syrup flow in the spray bar sections when applied in overlapped areas. The sprayings were carried out in eight places in completely randomized design. It was compared the spray consumption and the sprayed area in relation to the total area. The results indicated that in sprays performed with the automatic system there was an average savings of $17.2 \%$ of the sprayed volume. The sprayed area using the bar section's automatic control was an average $6.1 \%$ lower than the sprayed area with manual control.
\end{abstract}

KEYWORDS: precision farming and pesticide application technology.

\section{CONTROLE AUTOMÁTICO E MANUAL DE SEÇÕES DA BARRA DE PULVERIZAÇÃO}

RESUMO: O emprego de recursos da agricultura de precisão na tecnologia de aplicação pode melhorar a eficácia durante as pulverizações. Assim, este trabalho teve por objetivo comparar os sistemas automático e manual de interrupção do fluxo de calda nas seções da barra de pulverização quando da sobreposição de locais aplicados. As pulverizações foram realizadas em oito locais diferentes, em delineamento inteiramente casualizado. Compararam-se o consumo de calda e a área pulverizada em relação à área real. Os resultados indicaram que, nas pulverizações realizadas com o sistema automático, houve economia média de 17,2\% do volume de calda. A área pulverizada, utilizando-se do controlador automático de seções de barra, foi na média 6,1\% menor do que a área pulverizada com controle manual de seções de barra.

PALAVRAS-CHAVE: agricultura de precisão e tecnologia de aplicação.

\section{INTRODUCTION}

Brazil leads the world consumption of agrochemicals, which moved in 2008 US\$ 7.1 billion (ABIFINA, 2011). The use of chemical control,when necessary, should employ all scientific knowledge to provide the correct placement of the biologically active product on target, in the required amount, in an effectively cost and with a minimum of environmental contamination (BOLLER et al., 2008; MATTHEWS, 2008).

Technological innovations such as the Global Navigation Satellite Systems (GNSS) enabled the expansion of the precision agriculture, which deals with the management of spatial variability of production and on the involved factors, enabling the application of agricultural inputs in a localized form and only in the amount required for the purpose of enabling the elevation of efficiency of the

\footnotetext{
${ }^{1}$ Engenheiro Agrícola, Prof. Dr., Depto. de Ciências do Solo e Engenharia Agrícola, Universidade Estadual de Ponta Grossa, Ponta Grossa - PR, fone: (42) 3220 3092, lama1@uepg.br.

${ }^{2}$ Engenheiro Agrônomo. Fazenda Vale do Jotuva, Carambeí - PR, rik_meer@hotmail.com.

${ }^{3}$ Engenheiro Agrônomo. Fazenda Vale do Jotuva, Carambeí - PR, ptvink@hotmail.com.

${ }^{4}$ Engenheiro Agrônomo, Prof. Dr,. Depto. de Ciências do Solo e Engenharia Agrícola, Universidade Estadual de Ponta Grossa, Ponta Grossa - PR, ajustino@uepg.br.

${ }^{5}$ Engenheiro Agrônomo, Prof. Dr., Depto. de Ciências do Solo e Engenharia Agrícola, Universidade Estadual de Ponta Grossa, Ponta Grossa - PR, lcgarcia@uepg.br. 
process and reducing the impact on the environment (LIMA et al., 2006; CIRANI \& MORAES, 2010).

The precision agriculture adopted technology based in sprays that automatically shuts down spraying on the bar section which overlaps an area previously applied (SHARDA et al., 2010). Thus, it can avoid crashes and rollovers by improving the quality of the application, saving pesticides, fuel and time during the application process; resulting in greater operational efficiency, reducing operator's mental efforts, decreasing their fatigue and increasing the quality of the work.

To propose a methodology for evaluating the equipment that automatically controls the syrup flow in the spray bar sections, REYNALDO \& MOLIN (2011) evaluated three methods of positioning with the GPS (internal algorithm SBAS and RTK), three angles for the input and output simulation of the spray bar in relation to the edge of the plot (zero, $45^{\circ}$ and $60^{\circ}$ ) and three working speeds $\left(1.7,5.0\right.$ and $\left.8.3 \mathrm{~m} \mathrm{~s}^{-1}\right)$. The researchers concluded that although there were cases where certain GPS signal stood out compared to others, it cannot be concluded what was the best form since there are other factors with the greatest influence on the results, as, for example, the angle, the speed or even the interaction of both.

Comparing automatic and manual control of the sections of a spray in three areas in Shelby County, Kentucky, USA, LUCK et al. (2010) reported the reduction of the area applied for the implementation of approximately $8.0 \%$ of technology to bars divided into three sections, $11.0 \%$ with bar divided into five sections and up to $17.5 \%$ in spray bars divided in 30 sections .

The so-called mechanization costs represent the second component of the production cost in rural activity, behind only to the inputs. Therefore, in properties that use mechanization in production, the monitoring studies performed by machines and agricultural implements should deserve more attention (SICHONANY, et al., 2011).

With the possibility of adoption the technology on automatic interruption of the syrup flow on the spray bar sections when applied in overlapped areas, the objective of this study was to evaluate the effectiveness of this system compared to the manual, as the consumption of syrup and sprayed area.

\section{MATERIAL AND METHODS}

The experiment was conducted in an agricultural production unit named Ribeiros, $24^{\circ} 57^{\prime} 30^{\prime}$ ' South latitude, $49^{\circ} 58$ ' 24" West longitude, Cfb climate, municipality of Carambeí, PR. The areas were selected with different requirements for manoeuvre in spraying, by variation of shape and size, numbered from 1 to 8 (Figure 1).

An Amazon 1200 spray (Stara ${ }^{\circledR}$ S/A Implements Industry, Não-Me-Toque - RS), mounted on a tractor 6,600 (John Deere ${ }^{\circledR}$, Horizontina-RS) were used with rear tank 1,200 liters and front tank with capacity for 800 litres of spray, $24 \mathrm{~m}$ bar, divided into seven sections; being the sections 1, 2, 6 and 7 each composed of six nozzles and sections 3, 4 and 5, with eight nozzles each, totaling 48 nozzles spaced $0.5 \mathrm{~m}$ fixed in brackets to a diaphragm check valve, with an application range of 24 m (Figure 2).

The tip employed was TTI 110015-VP (Teejet ${ }^{\circledR}$, Wheaton, Illinois, USA). The volume of water without agrochemicals used was $90 \mathrm{~L} \mathrm{ha}^{-1}$ (typically employed in the operation of desiccation, simulated in the experiment), the pressure of around $320 \mathrm{kPa}$ and the working speed of $2.3 \mathrm{~m} \mathrm{~s}^{-1}$.

To maintain the same flow, the work speed variations were compensated automatically by the change of pressure between 100 and $600 \mathrm{kPa}$ by the spray computers. The tractor worked with 1600 RPM rotation so that the TDP kept 540 RPM required by the hydraulic pump sprayer.

Spray adjustment took place by evaluating the syrup stirring, working pressure in the spray tips, elimination of leaks, conference of $0.5 \mathrm{~m}$ spacing between nozzles, hydraulic circuit sieves 
with 100 meshes and flow variation less than $10 \%$ between the spray tips. The data of the syrup volume applied and the spray area, recorded by the onboard computer, were calibrated in an area of $2,000 \mathrm{~m}^{2}$ with five repetitions.


FIGURE 1. Areas sprayed with spray boom section's automatic and manual flow interruption control. 

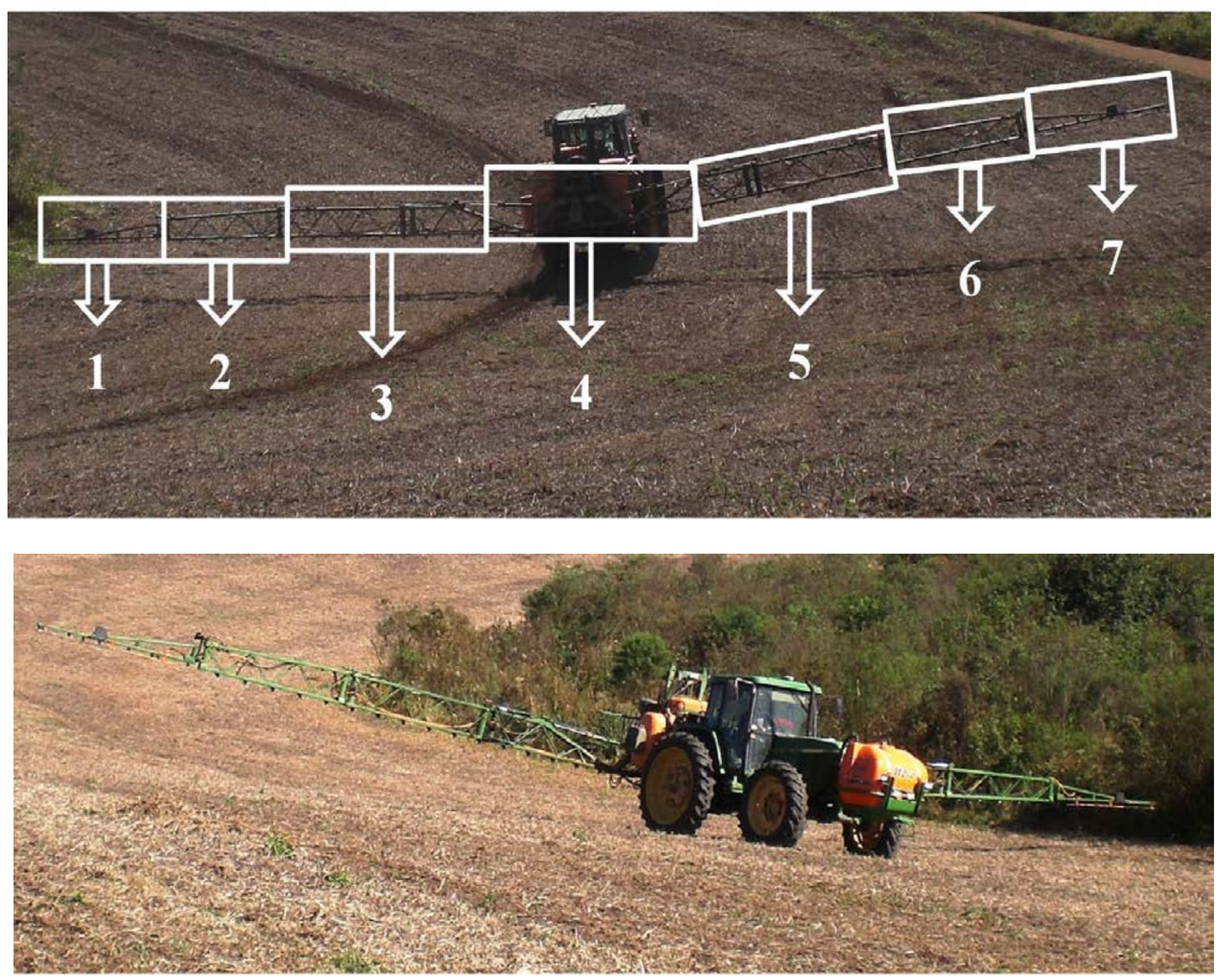

FIGURE 2. Spraying set used for automatic and manual flow interruption control in each one of the seven boom sections.

The automatic control system of spray bar sections used was the AgGPS EZ-Boom 2010 (Trimble Navigation Limited $^{\circledR}$, Sunnyvale, CA, USA), which can control from 1 to 10 sections, working in the application rate control. The guidance system had $0.17 \mathrm{~m}$ color display and 31 LEDs for quick view and orientation, a USB port for transferring the operations log files and connection to the automatic pilot system AgGPS EZ-Steer (Trimble Navigation Limited ${ }^{\circledR}$, Sunnyvale, CA, USA). This technology allowed the reading of the pass in the area to be sprayed with the automatic pilot.

The antenna of the GPS receiver, with the internal algorithm feature of filtered position errors ("firmware"), was fixed on the roof of the cabin and connected to the controller bar sections and automatic spraying, both being installed in the tractor cabin. The sections and spray controller was connected directly to the electric valves and flow control Bravo 400 (ARAG ${ }^{\circledR}$, Rubiera, Italy), which are responsible for the opening and closing of each section of the spray bar and for maintaining the pre-established flow.

The trial was held in such a way that each site was sprayed twice. On the first spraying we used the sections control system. In the second, the control spraying of the sections was manual. In each application, the surrounding was done first then started the spraying. In the spraying the operator oriented by the traces left by the tractor operating on automatic pilot mode.

On the automatic spraying, throughout the course of each area, the control of sections remained active, working in automatic mode. In the manual spraying the controller screen was disabled, preventing the operator could be geared for the information on this, forcing him to use the control sections manually. 
The experiment was accomplished in April 2011, with variation in temperature of $12^{0} \mathrm{C}$ to $17^{0} \mathrm{C}$ during the conduction of it, wind speed between $0.3 \mathrm{~m} \mathrm{~s}^{-1}$ and $2.5 \mathrm{~m} \mathrm{~s}^{-1}$ and relative humidity of $55 \%$ to $77 \%$. The weather conditions were monitored by the anemo-thermo-hygrometer 3,000 $\left(\right.$ Kestrel $^{\circledR}$, Chester, USA).

The variables analyzed were volume of spray and sprayed area. The values of volume of spray, in litres spent at each location on spraying with automatic control and manual control, were compared with values for volume of ideal spray for each location. This is equivalent to the volume of application of $90 \mathrm{~L} \mathrm{ha}^{-1}$, multiplied by the actual area of each site. That is, if considered an application without failure, overlap and variation. In this way, the percentages were calculated on spray consumption for each treatment, in relation to the ideal spray volume for each area. The same reasoning was held regarding the area sprayed.

It was used a completely randomized design; and each area was considered a repetition, totaling eight. It was used the Hartley test to verify the homocedasticity and the F test (5\%) for analysis of variances.

\section{RESULTS AND DISCUSSION}

The Hartley test pointed the homocedasticity of the variances for all studied variables. Therefore, there was no need for transformation of the averages for application of the F-test. On table 1, are shown the volumes of spray used in each location of the experimental area for the treatments with automatic and manual spraying system, as well as, the calculated values of volume of ideal syrup for each location, considering its area, multiplied by the volume of pre-established application in $90 \mathrm{~L} \mathrm{ha}^{-1}$.

The spray speed was maintained close to $2.3 \mathrm{~m} \mathrm{~s}^{-1}$ in the sprayed area. However, the eight different worked areas required input and output angles of the spray bar in relation to the edge of the field, according to studies by REYNALDO \& MOLIN (2011).

The addition of variations volume applied in relation to the in different areas ranged from 12.9 to $40.9 \%$ in the manual system and 5.2 to $30.6 \%$ in the system that automatically stops spraying in the spray bar section to overlap a previously applied area. The automatic system presented the average volume of spray sprayed in area of $12.4 \%$ and the manual system with $29.6 \%$ higher than the volume of spray sprayed compared to the ideal.

The waste of spray sprayed is too high, however, embedded technology significantly reduced the losses of 17.2\%. Extrapolating the average volume reduction applied to the condition of national spending on agrochemicals in 2008 (ABIFINA, 2011), would be a savings of $\$ 1.2$ billion.

On the assumption that the property where the experiment was conducted has 800 hectares cultivated with two harvests per year, there are an average of 12 sprays per year. When comparing the automatic and manual system control of the sections would have a saving of 15,973 L annually. 
TABLE 1. Syrup volumes used in automatic and manual control of spray interruption of the spraying bar section compared with the ideal stipulated (90 L ha'), Carambeí (PR).

\begin{tabular}{llllll}
\hline & \multicolumn{2}{l}{ Syrup volume (L) } & & $\begin{array}{l}\text { Relationship between the sprayed syrup and the } \\
\text { ideal ( \% ) }\end{array}$ \\
\cline { 2 - 7 } & Automatic & Manual & Ideal & Automatic & Manual \\
\hline Area 1 & 253 & 277 & 218 & +16.1 & +27.1 \\
\hline Area 2 & 203 & 246 & 194 & +4.6 & +26.8 \\
\hline Area 3 & 176 & 221 & 162 & +8.6 & +36.4 \\
\hline Area 4 & 855 & 951 & 786 & +8.8 & +21.0 \\
\hline Area 5 & 712 & 764 & 677 & +5.2 & +12.9 \\
\hline Area 6 & 303 & 364 & 271 & +11.8 & +40.9 \\
\hline Area 7 & 528 & 654 & 464 & +13.8 & +37.4 \\
\hline Area 8 & 614 & 646 & 470 & +30.6 & $+29.6 \mathrm{~b}$ \\
\hline Sum & 3.644 & 4.123 & 3.242 & &
\end{tabular}

2 - Medium followed by different letters in the line differ significantly by the $\mathrm{F}$ test $(\mathrm{P}>0.05)$.

When analyzing the sprayed area in the automatic spraying interrupt control system in the bar section on different plots, compared to the actual area, there was an increase between $1.7 \%$ and $14.5 \%$, while the manual system of interruption of syrup flow in the spray bar sections ranged between $5.3 \%$ and $21.7 \%$ (Table 2 ).

TABLE 2. Areas sprayed with automatic and manual system of spray interruption control in the spray bar section in comparison with the actual area of each site, Carambeí (PR).

\begin{tabular}{llllll}
\hline & \multicolumn{2}{l}{ Sprayed Area (ha) } & Area (ha) & $\begin{array}{l}\text { Relationship between sprayed area and the } \\
\text { actual area(\%) }\end{array}$ \\
\cline { 2 - 6 } & Automatic & Manual & Real & Automatic & Manual \\
\hline Area 1 & 2.77 & 2.93 & 2.42 & +14.5 & +21.1 \\
\hline Area 2 & 2.29 & 2.37 & 2.16 & +6.0 & +9.7 \\
\hline Area 3 & 1.96 & 2.19 & 1.8 & +8.9 & +21.7 \\
\hline Area 4 & 9.09 & 9.7 & 8.73 & +4.1 & +11.1 \\
\hline Area 5 & 7.83 & 7.92 & 7.52 & +4.1 & +5.3 \\
\hline Area 6 & 3.06 & 3.18 & 3.01 & +1.7 & +5.6 \\
\hline Area 7 & 5.43 & 5.82 & 5.15 & +5.4 & +13.0 \\
\hline Area 8 & 5.56 & 5.87 & 5.22 & +6.5 & +12.5 \\
\hline Sum & 38.0 & 40.0 & 36.0 & & $+12.5 \mathrm{~b}$ \\
\hline Average & 4.7 & 5.0 & 4.5 & $+6.4 \mathrm{a}^{2}$ & \\
\hline 2- Medium followed by different letters in the line differ significantly by the $\mathrm{F}$ test $(\mathrm{P}>0.05)$. &
\end{tabular}

The average registered in the automated system, a value $6.4 \%$ higher; while in the manual system the sprayed area was $12.5 \%$ higher than the actual area (Figure 3 ). 


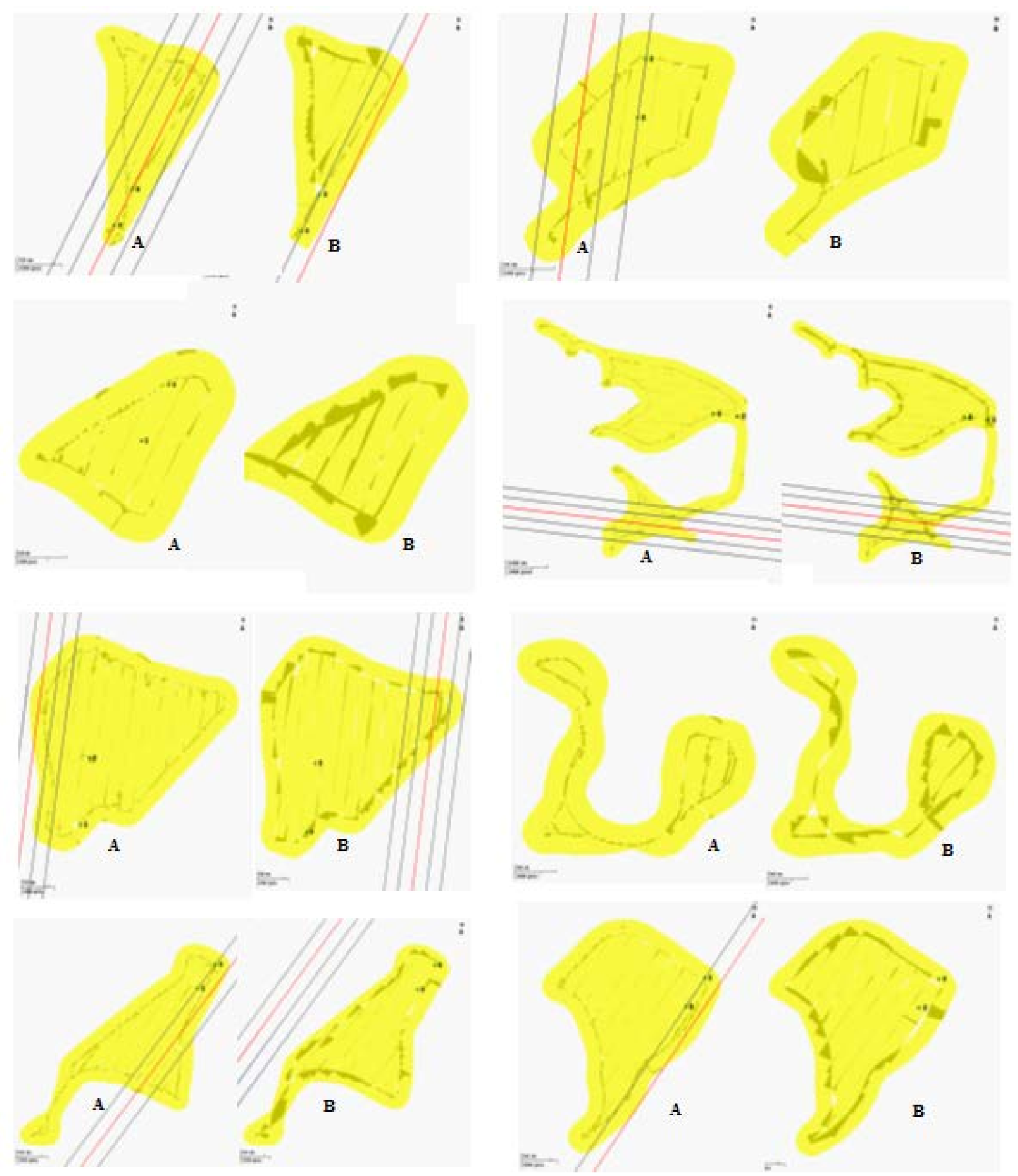

FIGURE 3. Sprayed areas (yellow) with boom section's automatic (A) and manual (B) flow interruption control, highlighting the fails in white and overlapping in green.

The waste of time, fuel, labour and pesticides occurred, but the reducing of the spray overlap in the control system of automatic sections was $6.1 \%$ lower than in the control system of manual sections; these values were significant with a degree of confidence higher than $95 \%$ probability for the F-test.

Precision farming allowed to reduce the volume of waist of pulverized syrup and environmental contamination. Therefore, meets the concepts presented by LIMA et al. (2006), BOLLER et al. (2008), MATTHEWS (2008), CIRANI \& MORAES, (2010) and SHARDA et al. (2010). 
The values are lower than those obtained by LUCK et al. (2010) when comparing the automatic control of the sections with the manual control system, registered a reduction in the area applied for technology deployment in approximately 8.0\% for bars divided in three sections.

When the bar was divided into five sections, the sprayed area reduced up to $11.0 \%$ and $17.5 \%$ with bars divided in 30 sections. As the areas and equipment used in both experiments have differentiated characteristics it is not recommended to correlate the experiments as to the percentage of the effectiveness of the technology, but rather, about the comparison of the significant reduction of the sprayed area between automatic and manual systems.

According to the ABC FOUNDATION (2011) the difference between automatic and manual control of the interruption of the syrup flow in the spray bar is R $\$ 0.30$ per hectare. In an area of 800 ha with 12 annual sprays the technology raises the cost in R 2,200.00. And with the economy of $6.1 \%$ from the sprayed area with automatic control of the sections compared to the manual, there is a reduction of 586 hectare sprayed or $\mathrm{R} \$ 5,680.32$. Therefore in the experimental conditions the technology would pay an annual balance of $\mathrm{R} \$ 3,480.32$.

\section{CONCLUSIONS}

Spraying performed with automatic controller of the syrup flow interruption on the bar sections allow an average savings on spray volume of $17.2 \%$, compared with the manual system. The sprayed area using the automatic controller bar sections was on average $6.1 \%$ lower than the sprayed area with control of sections on manual bar.

Despite the increase in technology efficiency on application and reduction of environmental pollution, the automatic technology system also spent $12.4 \%$ more spray volume than the ideal and $6.4 \%$ increase of sprayed area compared to the actual one.

Experimental conditions and the embedded technology was economically viable.

\section{REFERENCES}

ABIFINA. Defensivos Agrícolas. Disponível em: <http://www.abifina.org.br/estatisticas.asp.> Acesso em: 18 mar. 2011.

BOLLER, W.; HOFFMANN, L.L.; FORCELINI, C.A.; CASA, R.T. Tecnologia de aplicação de fungicidas - parte II. Revisão Anual de Patologia de Plantas, Passo Fundo, v.16, p.85-132, 2008.

CIRANI, C.B.S.; MORAES, M.A.F.D. Inovação na indústria sucroalcooleira paulista: os determinantes da adoção das tecnologias de agricultura de precisão. Revista de Economia e Sociologia Rural, Piracicaba, vol.48, n.4, p. 543-565, 2010.

FUNDAÇÃO ABC. Planilha de custos de mecanização agrícola. Castro: Fundação ABC, 2011. 01p.

LIMA, T.C.B.; UMEZU, C.K.; CAPPELLI, N.L.; NUNES, E.F. Equipamento microprocessado para geração de sinal de correção diferencial, em tempo real, para GPS. Engenharia Agrícola,

Jaboticabal, v.26, n.2, p.537-545, 2006.

LUCK, J.D.; PITLA, S.K.; SHEARER, S.A.; MUELLER, T.G.; DILLON, C.R.; FULTON, J.P.; HIGGINS, S.F. Potential for pesticide and nutrient savings via map-based automatic boom section control of spray nozzles. Computers and Electronics in Agriculture, New York, v. 70, p. 19-26, 2010.

MATTHEWS, G. A. Developments in application technology. Environmentalist, Hampshire, v. 28, p. 19-24, 2008.

REYNALDO, E.F.; MOLIN, J.P. Proposta metodológica para avaliação de controlador automático de seções e pulverização. Engenharia Agrícola, Jaboticabal, v.31, n.1, p.111-120, 2011. 
SICHONANYI , O.R.A.O.; SCHLOSSER, J.F.; MEDINA, R.D.; ROGGIA, I.B.; LÔBO, J.S.; SANTO, F.B. Sistema computacional de gerenciamento para acompanhamento de desempenho de máquinas agrícolas instrumentadas com sensores. Ciência Rural, Santa Maria, v. 41, n. 10, p. 17731776, 2011.

SHARDA, A.; FULTON, J.P.; McDONALD, T.P.; ZECH, W.C.; DARR, M. J.; BRODBECK, C.J. Real-time pressure and flow dynamics due to boom section and individual nozzle control on agricultural sprayers. American Society of Agricultural and Biological Engineers, Pittsburgh, v. 53, n. 5, p. 1363-1371, 2010. 